\title{
Profil Hematologi pada Rusa Timor (Cervus timorensis) Betina Berahi yang Disuplementasi Mineral pada Satu Siklus Berahi
}

\author{
Profile of Hematology of Female Timor Deer (Cervus timorensis) Suplemented with Minerals \\ in Estrus Cycle
}

\author{
A. Safithri, D. Samsudewa, dan Isroli \\ Fakultas Peternakan dan Pertanian Universitas Diponegoro Semarang \\ Jl. drh. R. Soejono Koesoemowardojo, Tembalang, Kota Semarang 50275 \\ Email : amilliasafithri50@gmail.com
}

\begin{abstract}
The aim of this research was to evaluate the effect of mineral supplementation of Zinc (Zn), Selenium (Se) and Magnesium $(\mathrm{Mg})$ on the dynamic profile of Hematology during the estrus phase of Timor Deer. The benefits of this research is to provide information to the breeder that providing mineral supplementation can increase the levels of erythrocytes, haemoglobin levels and the value of dynamic which improves the hematocrit of estrogen so as to improve the quality ofestrous of Timor Deer. The benefits of this research was to provide information to breeder that supplementtion of mineral can increase the levels of erythrocytes, haemoglobin levels and the value of dynamic which improves the hematocrit of estrogen so as to improve the quality of estrous on the Timor Deer. Treatment were given to five female Timor deers of mineral and other 5 female Timor deers did not receive the supplementation of mineral for 8 weeks. Installment of vaginal spons with $20 \mathrm{mg}$ Medroxy Progesterone Acetat (MPA) was done for 16 days. Blood samples were collected for hematologic on profile analyse 0, 24, 72, 84, 96, 108, 120 and 144 hours after releasing of vagina spons, data were analized used T-test. The result showed that Erythrocyte number has significant difference $(\mathrm{P} \leq 0.05)$ during 72 hours after releasing of Vaginal Spons and highly significance difference $(\mathrm{P} \leq 0.01)$ during 96, 108 and 120 hours after releasing of vaginal spons. Hemoglobin number has significance difference $(\mathrm{P} \leq 0.05)$ during 108 hours after releasing vaginal spons. Hematocrit number has significance difference $(\mathrm{P} \leq 0.05)$ during $0,24,72,84$ and 96 hours after releasing vaginal spons and highly significance difference $(\mathrm{P} \leq 0.01)$ during 120 hours after releasing vaginal spons.
\end{abstract}

Key words : hematology profile, Timor deer, minerals

\begin{abstract}
ABSTRAK
Penelitian ini bertujuan mengetahui pengaruh suplementasi mineral seng ( $\mathrm{Zn}$ ), Selenium (Se) dan Magnesium (Mg) terhadap dinamika profil hematologi selama fase estrus Rusa Timor. Manfaat dari penelitian ini adalah memberikan informasi kepada penangkar bahwa pemberian suplementasi mineral dapat meningkatkan kadar eritrosit, kadar hemoglobin dan nilai hematokrit sehingga memperbaiki dinamika dari estrogen sehingga dapat memperbaiki kualitas berahi pada Rusa Timor. Perlakuan diberikan berupa suplementasi mineral pada 5 ekor rusa (T1) dan tanpa suplementasi mineral (T0) selama 8 minggu, dan dilanjutkan dengan pemasangan spon MPA selama 16 hari untuk dilakukan sinkronisasi berahi. Sampel darah diambil secara berurutan pada jam ke - 0, ke24, ke-72, ke-84, ke-96, ke-108, ke-120 dan ke-144 setelah pencabutan spon MPA untuk dilakukan pengamatan profil hematologi. Paremeter yang diukur meliputi jumlah eritrosit, kadar hemoglobin dan nilai hematokrit darah. Data yang diperoleh dianalisis menggunakan Uji-T. Hasil penelitian menunjukkan bahwa perbedaanperbedaan nyata $(\mathrm{P} \leq 0,05)$ total eritrosit pada jam ke -72 serta sangat nyata $(\mathrm{P} \leq 0,01)$ pada jam ke- 96,108 dan 120 . Terdapat perbedaan nyata $(\mathrm{P} \leq 0,05)$ kadar hemoglobin pada jam ke- 108 . Perbedaan nyata $(\mathrm{P} \leq 0,05)$ nilai hematokrit pada jam ke- $0,24,72,84$ dan 96 serta perbedaan sangat nyata $(\mathrm{P} \leq 0,01)$ terjadi pada jam ke- 120 .
\end{abstract}

Kata kunci : Profil hematologi, Rusa Timor, Mineral

\section{PENDAHULUAN}

Rusa merupakan satwa yang memiliki status konservasi yaitu satwa yang pemanfaatannya dilindungi oleh Undang- undang. Rusa yang banyak dikembangkan pada daerah tropik adalah rusa Timor. Rusa Timor (Cervus timorensis) merupakan salah satu contoh rusa yang ada di Indonesia yang 
memiliki potensi cukup baik untuk dikembangkan. Hampir semua bagian dari tubuh rusa dapat dimanfaatkan, antara lain daging, ranggah dan kulit. Selain itu rusa dapat dipelihara didalam penangkaran agar menjadi breeding stock dan dapat dipelihara dengan tujuan komersil lainnya (Atmoko, 2007).

Secara reproduksi, kendala yang dihadapi adalah pola perkembang biakan rusa yang bersifat non seasonal polyoestrus atau tidak mempunyai musim kawin dan dapat berahi berulang kali sepanjamg tahun (Drajat, 2000). Permasalahan lain yang ada pada rusa Timor adalah adanya musim kawin sehingga perkawinan tidak dapat dilakukan setiap waktu (Samsudewa dan Susanti, 2006).

Reproduksi yang baik ditunjang oleh kesehatan, dimana kesehatan dapat diduga dari profil hematologinya. Profil hematologi dapat ditingkatkan melalui kecukupan nutrisi terutama mineral esensial. Mineral esensial adalah mineral yang dibutuhkan dalam proses fisiologis dan kerja enzim dalam makhluk hidup, mineral esensial dibagi dalam dua golongan yaitu mikro mineral dan makro mineral pada (Arifin, 2008). Mikro mineral yang digunakan dalam penelitian adalah selenium (Se) dan zinc (Zn) karena Se dan Zn terbukti dapat mempengaruhi kualitas reproduksi pada ternak (Darmono, 2007), sedangkan makro mineral yang dipakai adalah magnesium (Mg). Suplementasi Zn dapat meningkatkan jumlah eritrosit, hemoglobin dan hematokrit sehingga dapat berfluktuasi (Widhyari, 2014). Ternak yang kekurangan Zn akan mengalami penurunan hemoglobin yang disertai dengan menurunnya eritrosit dan hematokrit sehingga menyebabkan anemia (Hoffbrand et al., 2005).

Fase estrus menyebabkan kadar estrogen tinggi sehingga memacu aliran darah meningkat yang berakibat pada konsumsi oksigen tinggi sehingga terjadi hiperoxia, sehingga ginjal melakukan inhibisi hormon eritropoitin dan menurunkan proses eitropoiesis (Hadley, 2000). Karena kadar estrogen yang tinggi dalam darah mengakibatkan volume plasma darah akan bertambah, menghambat eritropoeisis sehingga mengurangi kapasitas pengangkutan oksigen dan melambatnya proses pengangkutan komponen-komponen telur (Wagner et al., 2008). Eritropoitin merupakan hormon yang disekresi oleh ginjal dan berfungsi menstimulasi eritropoiesis. Eritropoiesis adalah pembentukan sel darah merah yang terbentuk dalam sumsum tulang yang merupakan suatu proses kontinu dan sebanding dengan tingkat perusakan sel darah merah (Sonjaya, 2012).

\section{MATERI DAN METODE}

Penelitian dilaksanakan pada bulan Maret sampai bulan Mei 2016 di Penangkaran Rusa Timor di desa Margorejo, Kecamatan Dawe, Kabupaten Kudus. Pengambilan sampel darah dan perhitungan total Eritrosit, kadar Hemoglobin serta nilai Hematokrit akan dilaksanakan pada penangkaran tersebut. 
Materi yang digunakan adalah darah Rusa Timor betina dewasa sebanyak 10 ekor yang mempunyai BCS (Body Condition Score) 2 - 3,25, poel 2, kondisi fisik baik dan sudah pernah partus sehingga menunjukkan kondisi reproduksi yang baik serta sampel darah rusa sebagai objek pengamatan. Pakan yang diberikan adalah hijauan berupa rumput gajah dan rumput lapang serta singkong. Air minum yang diberikan secara ad libitum, ditambah suplementasi mineral dalam bentuk mineral blok.

Alat yang digunakan dalam penelitian adalah alat pembuatan mineral blok antara lain blender, ember untuk mencampur bahan, timbangan untuk menimbang bahan, alat pencetak (press), tongkat pengaduk, kuas, oven. Bahan yang digunakan antara lain onggok, bekatul, bungkil kedelai, garam, molases, vitamin A, D,E, K, premix, $\mathrm{Mg}, \mathrm{Zn}$, Se dan air. Alat tulup untuk menyuntikkan obat penenang dan spon vagina. Alat pengambilan darah antara lain spuit $10 \mathrm{ml}$, tabung vakum dengan EDTA. Alat pengamatan sel darah merah antara lain hemocytometer neubauer, bilik hitung, hand counter, cover glass, mikroskop, beaker glass, tabung sahli, tabung mikrokapiler hematokrit, plastisin dan centrifuge untuk memisahkan sel darah merah, tissue dan tabel pengamatan. Bahan yang digunakan antara lain larutan Hayem, aquabides dan $\mathrm{HCl}$ 0,1 N.

Persiapan penelitian dilakukan pada kandang pengamatan dipasang MMT/terpal disekeliling kandang dengan tujuan memisahkan antara kandang tanpa perlakuan dengan kandang perlakuan dan menghindari rusa mengalami luka akibat benturan. Tempat air minum dan tempat pakan dibersihkan. Sepuluh (10) rusa betina dewasa yang dipilih dengan kriteria mempunyai BCS antara $2-3,25$, tidak ada cacat fisik dan sudah pernah partus, diberi tagging menggunakan selang air dengan warna yang berbeda untuk membedakan tiap individu kemudian dimasukkan dalam 2 kandang masing-masing berisi 5 ekor rusa.

Pembuatan mineral blok dimulai dengan mencampurkan bahan-bahan antara lain dedak, bungkil kedelai, onggok dan premix dalam ember kemudian aduk hingga homogen, kemudian mineral $\mathrm{Mg}$, Se dan $\mathrm{Zn}$ serta vitamin dan garam dimasukkan ke dalam molases aduk hingga homogen. Tuang perlahan larutan molases ke dalam ember dan aduk hingga semua homogen. Kemudian masukkan bahan tersebut ke dalam alat pencetak tekan hingga padat. Oven dengan suhu $60^{\circ} \mathrm{C}$ selama $24-48$ jam.

Pembuatan mineral blok dengan komposisi yang terdiri dari bahan utama, bahan pengisi serta bahan tambahan. Bahan utama terdiri dari molases, bahan pengisi terdiri dari dedak, onggok dan bungkil kedelai serta bahan tambahan yang terdiri dari garam, premix, vitamin A, D, E, K dan mineral antara lain $\mathrm{Ca}, \mathrm{P}, \mathrm{Na}, \mathrm{Mg}, \mathrm{Zn}$ dan Se. berikut ini Tabel 1. Menyajikan fomulasi mineral blok yang akan digunakan: 
Tabel 1. Formula mineral blok

\begin{tabular}{|c|c|c|}
\hline No. & Bahan & Persentase $(\%)$ \\
\hline 1. & Molases & 35 \\
\hline 2. & Bekatul & 40 \\
\hline 3. & Bungkil Kedelai & 10 \\
\hline 4. & Garam & 6 \\
\hline 5. & Onggok & 6.9 \\
\hline 5. & Vitamin & 0.04699 \\
\hline \multirow[t]{6}{*}{6.} & Mineral & \\
\hline & - $\quad$ Premix & 2 \\
\hline & $\mathrm{Mg}$ & 0,051 \\
\hline & $\mathrm{Zn}$ & 0,003 \\
\hline & $-\quad \mathrm{Se}$ & 0,00001 \\
\hline & Total & 100 \\
\hline
\end{tabular}

Pembuatan spon dengan ketebalan 4 $\mathrm{cm}$ dicetak menggunakan alat pencetak, benang dipasang pada spon dengan jarum, mencuci spon dengan air sabun hingga bersih, memasukkan spon dalam box pengering selama 48 jam, menambahkan larutan MPA dan methanol pada permukaan spon, masukkan kembali dalam box pengeringan selama 48 jam.

Sampel rusa dimasukkan dalam 2 kandang yang berbeda masing-masing kandang berisi 5 ekor rusa Penambahan mineral blok selama 2 bulan (8 minggu). Komposisi utamanya adalah Magnesium (Mg) sebanyak 20-40 mg/kg BK pakan, Selenium (Se) sebanyak 0,1-0,2 mg/kg BK pakan dan Seng (Zn) sebanyak 20-33 $\mathrm{mg} / \mathrm{kg}$ BK pakan (NRC, 1985).

Sinkronisasi estrus dilakukan dengan cara spon vagina dimasukkan kedalam servix dengan pipa aplikator dan tongkat pendorong yang sebelumnya telah diolesi $\mathrm{KY}$ jell agar tidak melukai dinding vagina rusa. Tujuan dilakukannya sinkronisasi estrus adalah untuk menyerentakkan fase estrus 10 ekor rusa. Pemberian obat penenang dilakukan dengan cara ACP sebanyak $0.5 \mathrm{ml}$ dimasukkan kedalam spuit, kemudian ditambah gas korek api agar cairan terdorong masuk kedalam tubuh rusa, spuit ditembakkan ke rusa sasaran pada bagian paha kaki belakang menggunakan pipa tulup. Obat penenang akan bereaksi kurang lebih dalam 30 menit, kemudian rusa digiring keluar kandang untuk kemudian dilakukan handling dan mata ditutup dengan kain hitam.

Darah diambil pada bagian vena jugularis pada daerah sekitar leher menggunakan spuit $10 \mathrm{ml}$ kemudian dimasukkan kedalam tabung vakum dengan EDTA (Ethylene Diamine Tetraacetic Acid), kemudian digoyang membentuk angka 8 selama 3 menit dan dimasukkan dalam cooling box yang berisi ice pack sebagai penyimpanan sementara agar sampel darah tidak menggumpal. Pengambilan darah dilakukan di 8 titik, yaitu:

- 0 jam setelah spon vagina dilepas (indikasi fase diestrus)

- 24 jam setelah spon vagina pelepasan (indikasi fase proestrus) 
- 72, 84, 96 dan 108 jam setelah pelepasan spon vagina (indikasi fase estrus)

- 120 dan 144 jam setelah pelepasan spon vagina (indikasi fase metestrus)

Darah yang telah terambil dalam tabung EDTA dimasukkan dalam cooling box dan selanjutnya dilakukan pengamatan profil hematologi.

Parameter yang diamati antara lain adalah perhitungan total eritrosit, kadar hemoglobin dan nilai hematokrit. Total eritrosit dihitung dengan metode kamar hitung (hemocytometer neubauer). Kadar hemoglobin menggunakan metode Sahli dan nilai hematokrit menggunakan metode mikrokapiler.

Data yang diperoleh dianalisis secara deskriptif untuk membandingkan fluktuasi dari waktu ke waktu pada kelompok rusa tanpa suplementasi mineral, guna mengetahui pengaruh suplementasi mineral terhadap profil hematologi dilakukan analisis uji beda menggunakan T-test. Hipotesis penelitian adalah :
$\mathrm{H} 0=$ tidak terdapat perbedaan profil hematologi tiap fase berahi antar individu Rusa Timor tanpa perlakuan dan yang diberi perlakuan suplementasi mineral.

$\mathrm{H} 1=$ terdapat perbedaan profil hematologi tiap fase berahi antar individu Rusa Timor tanpa perlakuan dan yang diberi perlakuan suplementasi mineral

\section{HASIL DAN PEMBAHASAN}

Hasil yang diperoleh dari pengamatan total eritrosit per $\mathrm{mm}^{3}$ dari tiap fase sebagaimana tertera pada Gambar 1. memperlihatkan bahwa terdapat fluktuasi jumlah rataan total eritrosit dalam darah pada kelompok yang tidak diberi perlakuan suplementasi mineral (T0) pada fase proestrus $5,18 \mathrm{jt} / \mathrm{mm}^{3}$ dan estrus relatif lebih rendah dari kisaran normal. Laak (2000) menyatakan bahwa gambaran darah Rusa Timor pada fase estrus memiliki rata-rata eritrosit sebesar $10,94 \mathrm{jt} / \mathrm{mm}^{3}$.

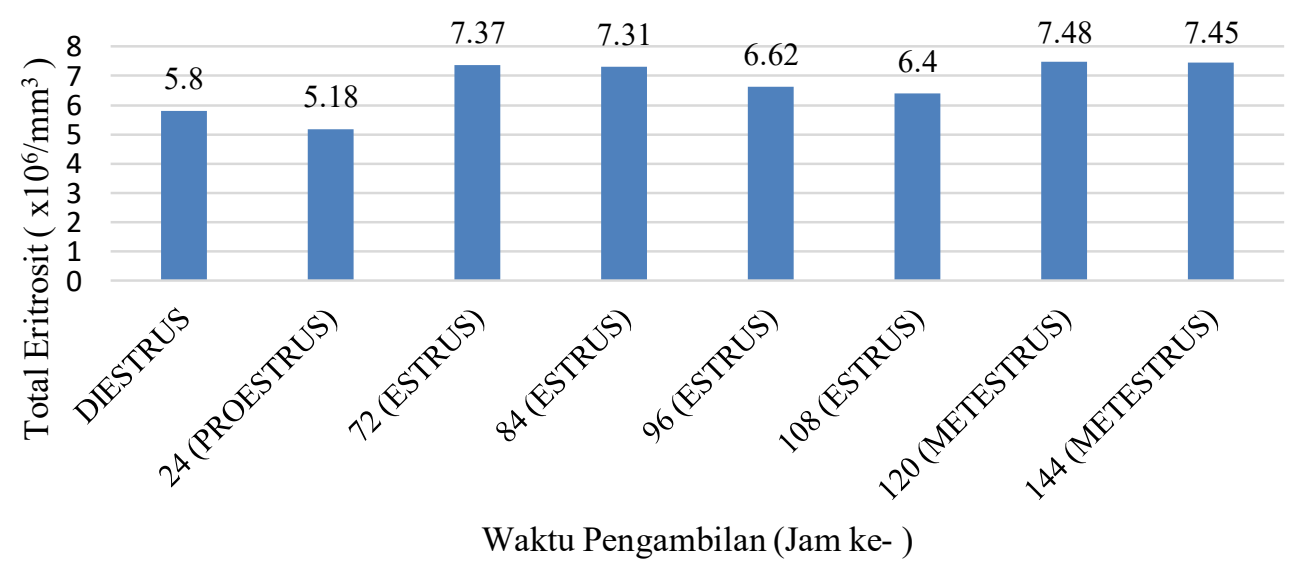

Gambar 1. Diagram batang rataan total eritrosit rusa tanpa suplementasi mineral

Saat ternak dalam fase estrus maka kadar estrogen meningkat menyebabkan profil hematologi akan menurun karena peningkatan volume plasma dan 
menghambat proses eritropeiesis sehingga total eritrosit dalam darah akan menurun. Wagner et al. (2008) menyatakan bahwa kadar estrogen dalam darah mengakibatkan volume plasma darah akan bertambah, menghambat proses eritropoiesis sehingga mengurangi kapasiatas pengangkutan oksigen. Rendahnya total eritrosit, kadar hemoglobin dan nilai hematokrit pada ternak dapat menyebabkan penurunan vitalitas dan terjadi anemia. Hadley (2000) menyatakan bahwa penyebab inhibisi eritropoiesis adalah meningkatnya kadar estrogen pada fase estrus sehingga memacu hormon aldosterone yang berakibat pada meningkatnya aliran darah dan konsumsi oksigen sehingga ternak mengalami hiperoxia, dimana hiperoxia memacu ginjal menghambat hormone eritropoitin dan menghambat adanya proses eritropoiesis.

Penurunan tersebut hanya terjadi sampai jam ke- 108 dan total eritrosit naik kembali pada jam ke- 120. Hal tersebut terjadi karena pada fase metestrus kadar estrogen menurun dan total eritrosit menjadi normal kembali. Penurunan total eritrosit pada saat jam ke-108 merangsang terjadinya eritropoeisis, sehingga pada jam ke 120 eritrosit darah menjadi normal kembali. Fase metestrus menyebabkan pembuluh darah pada uterus akan meluruh sehingga jumlah darah yang beredar didalam tubuh berkurang dan lebih banyak berisi plasma.

Hasil yang diperoleh dari pengamatan rataan kadar hemoglobin pada tiap fase sebagaimana tertera pada Gambar 2. memperlihatkan perbedaan jumlah rataan $\mathrm{Hb}$ dalam darah pada kelompok tanpa perlakuan suplementasi mineral (T0). Kadar hemoglobin pada tiap fase masih dibawah standar kadar hemoglobin normal yang berkisar 13\%. Laak (2000) menyatakan bahwa kadar normal hemoglobin adalah $13 \%$. Kadar hemoglobin yang rendah disebabkan karena kekurangan mineral, parasit dan juga karena stress. Siegmud (1979) menyatakan bahwa kadar hemoglobin menurun disebabkan karena kekurangan mineral, Vitamin E, vitamin B6 dan faktor lingkungan.

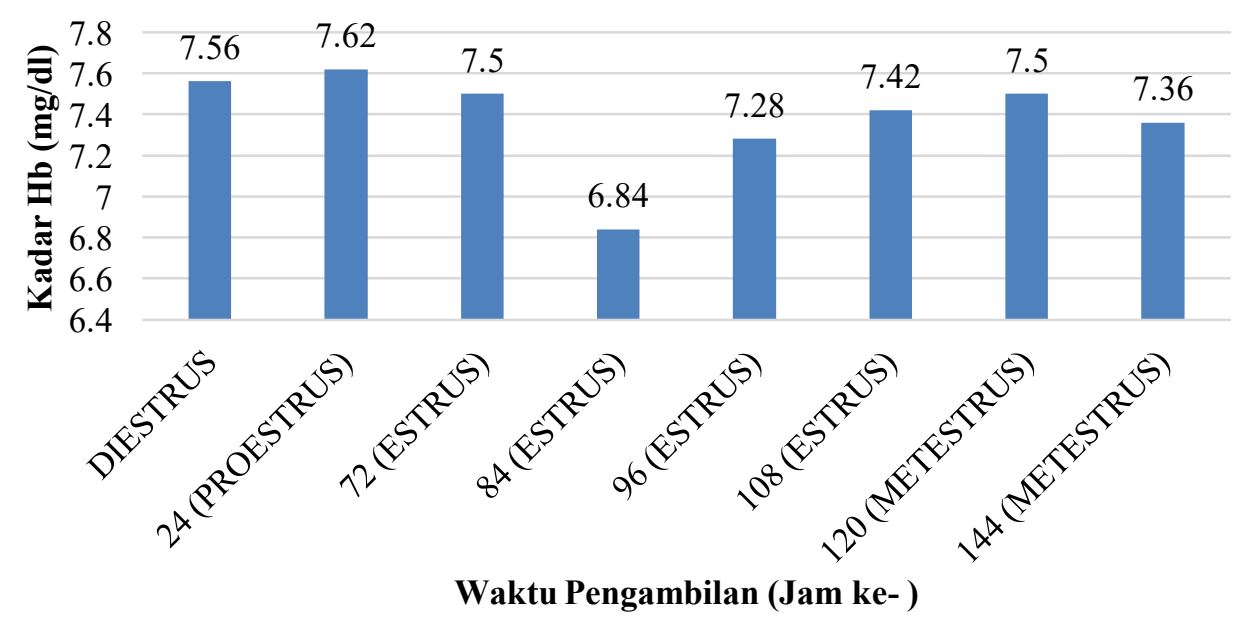

Gambar 2. Diagram batang rataan kadar hemoglobin rusa tanpa suplementasi mineral 
Penurunan drastis hemoglobin terjadi pada estrus jam ke- 84, hal tersebut terjadi karena rusa mengalami anemia. Anemia tersebut terjadi akibat jumlah eritrosit banyak namun ukurannya kecil, hal tersebut terlihat dari hitungan $\mathrm{MCH}$ yang rendah. Masrizal (2007) menyatakan bahwa secara morfologis penurunan kuantitatif pada sintesis hemoglobin disertai anemia mikrositik hipokrom. Rendahnya nilai hematokrit disebabkan oleh konsentrasi eritrosit yang menurun sehingga mengganggu proses metabolisme tubuh dan membawa zat nutrisi serta oksigen. Saryono et al. (2004) menyatakan bahwa hematokrit yang rendah memunculkan gejala kelemahan umum yaitu lesu dan penurunan aktifitas, penyebabnya adalah rendahnya konsentrasi eritrosit sehingga menggangu proses metabolism.

Hasil yang diperoleh dari pengamatan sebagaimana tertera pada Gambar 3. nilai hematokrit tiap fase berbeda-beda namun dibawah standar normal hematokrit yaitu 35\%. Laak (2000) menyatakan bahwa standar nilai hematokrit adalah 35\%. Rendahnya nilai hematokrit disebabkan oleh konsentrasi eritrosit yang menurun sehingga mengganggu proses metabolisme tubuh dan membawa zat nutrisi serta oksigen. Saryono et al. (2004) menyatakan bahwa hematokrit yang rendah memunculkan gejala kelemahan umum yaitu lesu dan penurunan aktifitas, penyebabnya adalah rendahnya konsentrasi eritrosit sehingga menggangu proses metabolisme.

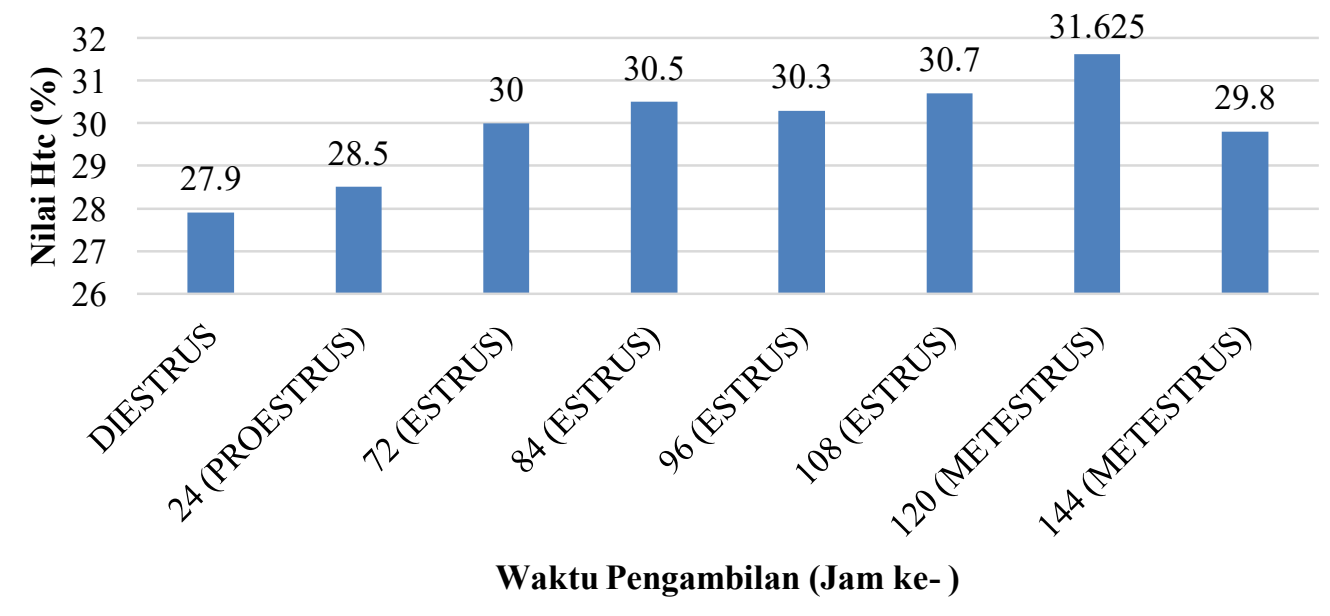

Gambar 3. Diagram batang rataan kadar hematokrit rusa tanpa suplementasi mineral

Profil hematologi (T0) lebih rendah dari kisaran normal dalam satu siklus estrus, penyebabnya adalah rendahnya konsumsi mineral dalam pakan yang diberikan, parasit, maupun stress. Siegmud (1979) menyatakan bahwa kadar hemoglobin menurun disebabkan karena kekurangan mineral, vitamin E, vitamin B6 dan faktor lingkungan. Faktor lingkungan antara lain adalah faktor eksternal yaitu dari pakan yang diberikan, pakan yang diberikan belum mencukupi kebutuhan mineral terutama $\mathrm{Zn}$ yang mempunyai fungsi menstimulasi eritropoiesis. Aksu et al., 
(2010) menyatakan bahwa defisiensi $\mathrm{Zn}$ adalah penyebab terhambatnya proses eritropoiesis.

Rendahnya profil hematologi terutama hemoglobin yang berfungsi mengangkut oksigen akan berakibat pada menurunnya vitalitas pada ternak, karena oksigen yang dialirkan dalam darah menurun sehingga menghambat aktifitas metabolisme sel. Frandson (1996) menyatakan aktifitas fisiologis dalam ovarium dipengaruhi oleh oksigen karena unsur tersebut dibutuhkan dalam metabolisme sel. Kasthama dan Eko (2006) menyatakan bahwa apabila kadar hemoglobin normal, maka oksigen dalam jaringan terpenuhi sehingga aktifitas fisiologi akan berjalan baiik termasuk dalam memproduksi estrogen.

Hasil pengamatan rataan total eritrosit sebagaimana tertera pada Tabel 2. memperlihatkan bahwa terdapat perbedaan jumlah rataan total eritrosit dalam darah pada kelompok yang diberi perlakuan suplementasi mineral (T1) dengan kelompok yang tidak diberi perlakuan suplementasi mineral (T0).

Tabel 2. Rata- rata total eritrosit rusa tanpa suplementasi (T0) dan yang disuplementasi mineral (T1) tiap fase estrus

\begin{tabular}{lccc}
\hline \multirow{1}{*}{ Fase } & Setelah Pelepasan Spon & \multicolumn{2}{c}{ Perlakuan } \\
\cline { 3 - 4 } & & T0 & T1 \\
\hline & $--------j a m--------$ & $-------j t / \mathrm{mm}^{3}-------------$ \\
Diestrus & 0 & 5,80 & 6,70 \\
Proestrus & 24 & 5,18 & 6,10 \\
Estrus & 72 & $7,37^{\mathrm{B}}$ & $9,67^{\mathrm{a}}$ \\
Estrus & 84 & 7,31 & 7,31 \\
Estrus & 96 & $6,62^{\mathrm{B}}$ & $9,58^{\mathrm{A}}$ \\
Estrus & 108 & $6,4^{\mathrm{B}}$ & $9,85^{\mathrm{A}}$ \\
Metestrus & 120 & $7,5^{\mathrm{B}}$ & $9,79^{\mathrm{A}}$ \\
Metestrus & 144 & 7,45 & 9,48 \\
\hline Rataan & & 6,7 & 8,56 \\
\hline
\end{tabular}

Keterangan : Huruf besar berbeda pada baris yang sama menunjukkan berbeda sangat nyata $(\mathrm{P}<0,01)$. Huruf kecil berbeda pada baris yang sama menunjukkan berbeda nyata $(\mathrm{P}<0,05)$.

Perbedaan nyata $(\mathrm{P} \leq 0,05)$ total Widhiyari et al. (2014) menyatakan bahwa eritrosit pada jam ke -72 serta sangat nyata suplementasi $\mathrm{Zn}$ memperlihatkan jumlah $(\mathrm{P} \leq 0,01)$ pada jam ke- 96, 108 dan 120, semua hasil lebih tinggi pada kelompok yang diberi suplementasi mineral (T1). Hal tersebut terjadi karena perlakuan eritrosit, hemoglobin dan hematokrit mengalami fluktuasi karena kandungan total $\mathrm{Zn}$ dalam darah terdistribrusi pada suplementasi mineral yang cenderung mengakibatkan total eritrosit berfluktuasi, mineral yang paling berpengaruh adalah $\mathrm{Zn}$. 
Saat ternak dalam fase estrus nilai rataan total eritrosit lebih rendah dibandingkan pada fase pro estrus, karena pada fase estrus kadar estrogen akan meningkat menyebabkan total eritrosit, kadar hemoglobin dan nilai hematokrit akan menurun karena peningkatan volume plasma dan menghambat proses eritropeiesis sehingga fungsi pengangkutan oksigen dalam darah akan menurun. Wagner et al. (2008) menyatakan bahwa kadar estrogen dalam darah mengakibatkan volume plasma darah akan bertambah, menghambat proses eritropoiesis sehingga mengurangi kapasiatas pengangkutan oksigen. Rendahnya total eritrosit, kadar hemoglobin dan nilai hematokrit pada ternak dapat menyebabkan anemia. Suplementasi mineral $\mathrm{Zn}, \mathrm{Mg}$ dan $\mathrm{Se}$ terbukti dapat mempengaruhi peningkatan profil hematologi, terutama Zn karena peningkatan eritrosit terlihat nyata setelah pemberian $\mathrm{Zn}$ dalam pakan selama satu bulan sehingga $\mathrm{Zn}$ dapat diserap secara maksimal. Menurut Azizzadeh et al. (2005) peningkatan jumlah eritrosit akan terlihat setelah satu bulan pemberian $\mathrm{Zn}$ yang dipengaruhi umur, sumber $\mathrm{Zn}$ dan kandungan $\mathrm{Zn}$ dalam pakan.

$\mathrm{Zn}$ dapat meningkatkan eritrosit karena $\mathrm{Zn}$ berfungsi menstabilkan antar skeletal membran yang terdiri dari dua lapisan (bilayer) serta mempertahankan protein skeletal, karena kerusakan bentuk membran dapat mempengaruhi masa hidup eritrosit. Gropper et al. (2005) menyatakan bahwa $\mathrm{Zn}$ dapat menstabilkan dan menyokong hubungan antar skeletal membrane dengan protein skeletal. Jain (1993) menyatakan bahwa membran terdiri dari dua lapisan fosfolipid (bilayer) dan kerusakan lapisan membran dapat berpengaruh pada masa hidup eritrosit.

$\mathrm{Zn}$ yang ditambah dengan $\mathrm{Cu}$ akan bekerja sama dengan enzim yang bernama dismufase superoxide yang akan bekerja untuk membuang anion-anion superoxide yang rusak dan merupakan radikal bebas, sehingga dapat menjaga keutuhan sel eritrosit, masa hidup eritrosit dan proses eritropoiesis tetap berlangsung. Gropper et al. (2005) menyatakan bahwa Zn merupakan salah satu nutrisi yang berfungsi untuk membuang radikal bebas. Patria et al. (2013) mennyatakan bahwa $\mathrm{Zn}$ dan $\mathrm{Cu}$ dapat menjaga keutuhan sel eritrosit dari rusaknya membrane akibat radikal bebas, sehingga masa hidup terjaga dan eritropeisis berlangsung dengan baik.

Hasil perhitungan kadar hemoglobin dari dari tiap fase sebagaimana tertera pada Tabel 2. memperlihatkan bahwa terdapat perbedaan perbedaan nyata $(\mathrm{P} \leq 0,05)$ kadar hemoglobin pada jam ke- 108 dalam darah pada kelompok yang diberi perlakuan suplementasi mineral (T1) dengan kelompok yang tidak diberi perlakuan suplementasi mineral (T0). mempunyai rata-rata yang lebih tinggi dibanding dengan (T0). 
Tabel 3. Kadar hemoglobin (Hb) Rusa tanpa suplementasi (T0) dan yang disuplementasi mineral (T1) tiap fase estrus

\begin{tabular}{lccc}
\hline Fase & Setelah Pelepasan Spon & \multicolumn{2}{c}{ Perlakuan } \\
\cline { 2 - 4 } & & T0 & T1 \\
\hline & ----- jam----- & --------- g/dL---------- \\
Diestrus & 0 & 7,56 & 8,69 \\
Proestrus & 24 & 7,62 & 7,63 \\
Estrus & 72 & 7,50 & 8,42 \\
Estrus & 84 & 6,84 & 7,62 \\
Estrus & 96 & 7,28 & 8,52 \\
Estrus & 108 & $7,42^{\mathrm{b}}$ & $7,93^{\mathrm{a}}$ \\
Metestrus & 120 & 7,50 & 7,97 \\
Metestrus & 144 & 7,36 & 8,10 \\
\hline Rataan & & 7,39 & 8,11 \\
\hline
\end{tabular}

Keterangan : Huruf kecil berbeda pada baris yang sama menunjukkan berbeda nyata $(\mathrm{P}<0,05)$

Rata-rata hemoglobin pada fase proestrus tidak mempunyai perbedaan nyata, hal tersebut karena kondisi awal yang sama sehingga kondisi fisiologis maupun hematologi yang juga tidak berbeda. Saat siklus estrus terjadi mulai menunjukkan adanya perbedaan fluktuasi kadar hemoglobin, pada (T1) lebih tinggi dibandingkan pada (T0). Hal tersebut disebabkan oleh suplementasi mineral, rendahnya kadar hemoglobin pada (T0) disebabkan oleh kekurangan mineral, parasit dan tingkat stress ternak. Menurut Kasthama dan Eko (2006) menyatakan bahwa rendahnya kadar hemoglobin disebabkan oleh kurangnya asupan mineral, parasit dan stress yang disebabkan oleh lingkungan sekitar. Rendahnya hemoglobin dapat menyebabkan anemia. Hoffbrand et al. (2005) menyatakan bahwa ternak yang kekurangan mineral (Zn) akan mengalami penurunan hemoglobin yang disertai dengan menurunnya eritrosit dan hematokrit sehingga menyebabkan menurunnya vitalitas tubuh dan anemia.
Anemia merupakan keadaan eritrosit maupun hemoglobin yang tidak dapat memenuhi kebutuhan oksigen bagi jaringan tubuh. Bakta (2014) menyatakan bahwa anemia ialah keadaan dimana massa eritrosit dan/atau massa hemoglobin yang beredar tidak dapat memenuhi fungsinya untuk menyediakan oksigen bagi jaringan tubuh dan secara laboratorik dijabarkan sebagai penurunan di bawah normal kadar hemoglobin, hitung eritrosit, dan hematokrit. Anemia terjadi pada kedua kelompok perlakuan, namun pada (T1) kadar hemoglobin lebih tinggi jika dibandingkan dengan (T0). Hal tersebut disebabkan oleh suplementasi mineral yang diberikan. Suplementasi mineral dapat mempengaruhi kualitas reproduksi dan peningkatan eritrosit, hemoglobin serta hematokrit pada ternak. Menurut Darmono (2007) mineral Se dan Zn terbukti dapat mempengaruhi kualitas reproduksi.

Hasil perhitungan nilai hematokrit dari tiap fase sebagaimana tertera pada Tabel 4. menunjukkan perbedaan 
nyata $(\mathrm{P} \leq 0,05)$ nilai hematokrit pada jam ke- $0,24,72,84$ dan 96 serta perbedaan sangat nyata $(\mathrm{P} \leq 0,01)$ terjadi pada jam ke120dalam darah pada kelompok yang diberi perlakuan suplementasi mineral (T1) dengan kelompok yang tidak diberi perlakuan suplementasi mineral (T0) dan (T1) mempunyai rata-rata yang lebih tinggi dibanding dengan (T0).

Tabel 4. Nilai hematokrit (Hct) rusa tanpa suplementasi (T0) dan yang disuplementasi mineral (T1) tiap fase estrus

\begin{tabular}{lccc}
\hline Fase & Setelah Pelepasan Spon & \multicolumn{2}{c}{ Perlakuan } \\
\cline { 2 - 4 } & & $\mathrm{T} 0$ & $\mathrm{~T} 1$ \\
\hline & $-------J a m-------$ & $----------(\%)------5^{\mathrm{a}}$ \\
Diestrus & 0 & $27,9^{\mathrm{b}}$ & $33,5^{\mathrm{a}}$ \\
Proestrus & 24 & $28,5^{\mathrm{b}}$ & $33,6^{\mathrm{a}}$ \\
Estrus & 72 & $30,0^{\mathrm{b}}$ & $35,0 \mathrm{a}$ \\
Estrus & 84 & $30,5^{\mathrm{b}}$ & $35,5 \mathrm{a}$ \\
Estrus & 96 & $30,3^{\mathrm{b}}$ & $33,6^{\mathrm{a}}$ \\
Estrus & 108 & 30,7 & 34,8 \\
Metestrus & 120 & $31,6^{\mathrm{B}}$ & $38^{\mathrm{A}}$ \\
Metestrus & 144 & 29,8 & 34,8 \\
Rataan & & 29,9 & 34,8 \\
\hline Keterangan $:$ Huruf kecil berbeda pada baris yang sama menunjukkan berbeda $(\mathrm{P}<0,05)$ \\
\multicolumn{2}{r}{ Huruf besar berbeda pada baris yang sama menunjukkan berbeda $(\mathrm{P}<0,01)$}
\end{tabular}

Perbedaan nilai hematokrit disebabkan oleh total eritrosit yang berbeda pula, karena faktor yang mempengaruhi nilai hematokrit adalah kerusakan, penurunan produksi, jumlah dan ukuran eritrosit. Menurut Wardhana et al., (2001) faktor yang memepengaruhi nilai hematokrit adalah kerusakan, penurunan produksi atau dipengaruhi oleh jumlah serta ukuran eritrosit. Penurunan hematokrit adalah salah satu indikator ternak mengalami anemia. Menurut Mahyaningtiyas (2016) Penurunan nilai hematokrit merupakan indikator anemia (karena berbagai sebab), reaksi hemolitik, leukemia, sirosis, kehilangan banyak darah, dan hipertiroid.

Profil hematologi pada (T1) lebih tinggi jika dibandingkan dengan (T0), hal tersebut dipengaruhi oleh pemberian suplementasi mineral pada (T1), namun keduanya masih dibawah standar normal. Hasil analisis data per fase estrus menggunakan T-test menunjukkan hasil bahwa tidak terdapat perbedaan nyata pada estrus (jam ke-108) dan fase diestrus. Rendahnya profil hematologi menyebabkan menurunnya vitalitas dan dapat menyebabkan anemia.

Suplementasi mineral berfungsi untuk meningkatkan profil hematologi karena hal tersebut berpengaruh dalam sekresi hormon estrogen yang dihasilkan oleh folikel dalam ovarium. Kadar estrogen dalam darah dipengaruhi oleh aktifitas fisiologis ovarium, sehingga ketersediaan oksigen dalam jaringan ovarium selalu dibutuhkan, jika kadar hemoglobin normal 
maka oksigen yang dibutuhkan oleh jaringan akan terpenuhi sehingga aktifitas fisiologis akan berjalan dengan baik Frandson (1992) menyatakan aktifitas fisiologis dalam ovarium dipengaruhi oleh oksigen karena unsur tersebut dibutuhkan dalam metabolisme sel. Menurut Kasthama dan Eko (2006) apabila kadar hemoglobin dalam darah normal, maka oksigen dalam jaringan akan terpenuhi karena fungsi hemoglobin yaitu mengangkut oksigen dari paru-paru ke seluruh jaringan sehingga aktifitas fisiologi akan berjalan dengan baik termasuk dalam memproduksi estrogen.

\section{KESIMPULAN}

Profil hematologi dalam satu siklus estrus rusa yang diberi suplementasi mineral ( $\mathrm{Mg}, \mathrm{Zn}$ dan $\mathrm{Se}$ ) meningkat atau lebih tinggi dibandingkan rusa tanpa suplementasi mineral.

\section{UCAPAN TERIMAKASIH}

Terimakasih kepada Direktorat Penelitian dan Pengabdian kepada Masyarakat, Direktorat Jendral Pendidikan dan Kementrian Riset dan Teknologi yang telah mendukung kegiatan penelitian ini melalui dana Fundamental 2016. Terima kasih juga kami ucapkan kepada Kelik Isharyudhono S.T. yang telah membantu pembuatan alatdan mineral blok, Lilik Krismiyanto, S. Pt., M. Si yang telah membantu analisis dan kepada Alam Surya Wijaya S. Pt. yang telah membantu dalam pembuatan spon vagina.

\section{DAFTAR PUSTAKA}

Atmoko, T. 2007. Prospek dan Kendala Pengembangan Penangkaran Rusa Sambar (Cervus unicolor brookei). Prosiding Seminar Pemanfaatan HHBK dan Konservasi Biodiversitas menuju Hutan Lestari, Balikpapan 31 Januari 2007.

Azizzadeh, M., M. Mohri, H.A. Seifi. 2005. Effect of oral zinc supplementation on hematology, serum biochemistry, performance, and health in neonatal dairy calves. Comparative Clinical Pathology. 14 (2): 6771.

Darmono. 2007. Penyakit defisiensi mineral pada ternak rumansia dan upaya pencegahannya. Balai Besar Penelitian Veteriner. Bogor. 26 (3).

Dradjat, A. S. 2000. Fertility diagnosis of timorensis deer (Cervus timorensis) semen during antler cycle. Prosidings Seminar Nasional Diagnosis Laboratoris, Klinis dan Nut risi Veteriner. 48-56.

Frandson, R. D. 1996. Anatomi dan Fisiologi Ternak. Gadjah Mada University Press. Yogakarta. Hal 395398.

Gropper, S. S., J. L. Smith and J. L. Groff. 2005. Advanced Nutrition and Human Metabolism. Fourth edition. Wardsworth. USA. 
Hoffbrand, A. V., J. E. Pettit dan P. A. H. Moss. 2005. Hematologi. Buku Kedokteran EGC. Jakarta.

Patria, D. A., K. Praseno dan S. Tana. 2013. Kadar hemoglobin dan jumlah eritrosit Puyuh (Coturnix coturnix japonica Linn.) setelah pemberian larutan kombinasi mikromineral $(\mathrm{Cu}$, $\mathrm{Fe}, \mathrm{Zn}, \mathrm{Co})$ dan vitamin (A, B1, B12, C) dalam air minum. Buletin Anatomi dan Fisiologi. 21 (1): 26-35.

Rizal, M. 2005. Pengaruh sponasi progesterone intravaginal terhadap timbulnya estrus pada domba garut betina. J. Indon.Trop. Anim. Agric. 30 (3): 167-171.

Samsudewa, D. dan S. Susanti. 2006. Studi Tingkah Laku Reproduksi Rusa Timor (Cervus timorensis) sebagai
Upaya Penangkaran di Kepulauan Karimun Jawa. Laporan Kegiatan

Sonjaya, H. 2013. Dasar Fisiologi Ternak. Institut Pertanian Bogor Press. Bogor. Wardhana, H. April, E. Kenanawati, Nurmawati, Rahmaweni, dan C.B. Jatmiko. 2001. Pengaruh Pemberian Sediaan Patikaan Kebo (Euphorbia hirta L) terhadap Jumlah Eritrosit, Kadar Hemoglobin, dan Nilai Hematokrit pada Ayam yang Diinfeksi dengan Eimeria tenella. Jurnal Ilmu Ternak dan Veteriner. 6 (2). Bogor.

Widhyari, S. D. 2012. Peran dan dampak defisiensi Zinc (Zn) terhadap sistem tanggap kebal. Departemen Klinik, Reproduksi dan Patologi Fakultas Kedokteran Hewan Institut Pertanian Bogor. 